Journal of Business \& Management (COES\&RJ-JBM)

ISSN (E): 2306-7179 ISSN (P): 2306-8043

Publisher: Centre of Excellence for Scientific \& Research Journalism, COES\&RJ LLC

Online Publication Date \& Issue: 1st October 2016, Vol.4, No.4, October 2016

http://centreofexcellence.net/J/JBM/JBM\%20Mainpage.htm

\title{
The Impact of Corporate Governance Principles on Intellectual Capital Efficiency in Jordanian Public Shareholding Industrial Companies
}

Firas Ameen Shatanawi

Ph.D Accounting

\section{Abstract:}

The study aims to define the principles of corporate governance and its impact on intellectual capital (human capital, structural capital, and relational capital) in Jordanian Public Shareholding industrial companies.

The author used two main methods to collect data. The first method was the analysis of previous studies, articles, research, periodicals, on the subject corporate governance and intellectual capital in a way that made it possible to build a theoretical framework for the study, establish a study model, determine the extent of adherence to the principles of corporate governance, and the ability to predict the efficiency of intellectual capital. The second method is the descriptive and analytical approach, which is based on the use of various statistical methods and standard for the analysis of financial data gathered from the reports of industrial companies, so as to measure the independent and dependant variables of the study.

The study population consisted of 63 Jordanian industrial public shareholding companies, comprising $88.7 \%$ of the size of the population of industrial companies in Jordan.

The study found a statistically significant effect for adhering to the principles of corporate governance on intellectual capital efficiency (human capital, structural capital, and relational capital) in the Jordanian Public Shareholding industrial companies. The study also produced a number of related results, as well as recommendations for industrial companies, managements, and interested academics.

Keywords:

Corporate Governance, Intellectual Capital, Efficiency, Jordanian Public Shareholding

\section{Citation:}

Shatanawi, Firas Ameen (2016); The Impact of Corporate Governance Principles on Intellectual Capital Efficiency in Jordanian Public Shareholding Industrial Companies; (COES\&RJ-JBM) Vol.4, No.4, pp.204-219. 


\section{Chapter One: General Framework of the Study}

\subsection{Introduction}

Corporate governance has always been a subject of controversy and debate between parties concerned with accounting literature, whether they were researchers or specialized academics. Many studies have been conducted, particularly in the last three decades, to study the substance of this issue and discuss its different dimensions, since this subject has a role in the regulation of the relationship between shareholders, employees, board of Directors, and executive management on one hand, and stakeholders, like investors, creditors, customers, and others who are involved with the company, on the other hand, not to mention this topic adds more transparency to the administration.

The subject of corporate governance has been met with great interest by international organizations, especially the Organization for Economic Co-operation and Development (OECD), the International Finance Corporation of the World Bank, and Bank for International Settlement (BIS) represented in the Basel Committee's first, second, and third statements, which have developed guidelines to strengthen management in order to monitor business performance and enhance disclosure and transparency to serve all stakeholders.

Besides the interest in this subject, and with the onset of the hidden assetsera, (any assets not shown in the financial statements), and due to the rapid development of private technology like communication and computer technologies, and the increase in innovation and creativity, as well as globalization, international competition, and the emergence of new needs, the human factor is becoming the pillar of the economy. Companies have discovered a new type of hidden assets based on knowledge wealth, which has become another kind of assets called cognitive or intellectual assets.

The concept of intellectual capital is a modern one that has emerged to the business arena quite recently. Its affect has passed to the Arab world in the midst of the last century, and despite the importance of this issue and its significant role in the organization, it has not been given enough attention by Arab organizations. Most of them were only theoretically interested, as some organizations held conferences and symposiums, while a number of authors discussed this subject in their researches. Perhaps this lack of interest in the practical aspect of this subject is due to the fact that most organization do not understand the importance of this issue and its impact on the performance of organizations, while their focus on other topics preclude attention to intellectual capital.

\section{1-2 Importance of the study}

The study derives its importance by addressing the topic of corporate governance as a method of tracking organizations to attain a level of transparency, disclose their statements, and regulate the relationship between parties, like the company's shareholders, employees, Board of Directors, and executive management on one hand, and stakeholders, like investors, creditors, customers, and others who are involved with the company, on the other hand, thus ensuring the protection of their interests. The significance of this study is manifested in the highlighting of the intellectual capital and its components (human, structural, and relational) as one of the modern concepts related to organizations keeping pace with the requirements of the knowledge era and knowledge-based economy. The study illustrates the impact that the principles of corporate governance may have on the intellectual capital in the Jordanian Public Shareholding Industrial Companies. 


\subsection{Objectives of the study}

This study aims to define the principles of corporate governance and its impact on intellectual capital (human capital, structural capital, and relational capital) in Jordanian Public Shareholding industrial companies.

\section{1-4 Problem of the study}

Intangible assets account for a large proportion of the capital of many organizations in the current time. The industrial companies, like other organizations and institutions, seek to achieve growth, survive, reach global markets, and own a large stake in it. They need to own these assets to be able to address the challenges they face. Perhaps the most prominent challenges industrial companies face is protecting the interests of all parties associated with the companies in order to ensure their survival and continuity. Commitment to the principles of corporate governance is a mean to achieve this, due to what transparency adds to management: It regulates the relationship between the company's shareholders, staff, Board of Directors, and others, and protects the interests of the state from manipulation and corruption, thus achieving economic development.

Accordingly, this study looks in to the impact of corporate governance on the intellectual capital with all of its components on the Jordanian Public Shareholding industrial companies. These companies play a major role in the Jordanian economy and hold the elements of intellectual capital; therefore the problem of the study is an attempt to answer the following question:

Do the principles of corporate governance have an effect on the intellectual capital (human, structural, and relational) in the Jordanian Public Shareholding industrial companies?

\section{1-5 Study hypotheses}

The following hypotheses were formulated after looking into the study's questions:

First main hypothesis H0-1: There is no statistically significant affect for the principles of corporate governance on the human capital in Jordanian Public Shareholding industrial companies.

Second main hypothesis H0-2: There is no statistically significant affect for the principles of corporate governance on the structural capital in Jordanian Public Shareholding industrial companies.

Third main hypothesis H0-3: There is no statistically significant affect for the principles of corporate governance on the relational capital in Jordanian Public Shareholding industrial companies. 


\section{1-6 Study Model}

The following figure demonstrates the proposed study model:

\begin{tabular}{|l|l|}
\hline $\begin{array}{l}\text { Independent Variables: Principles of } \\
\text { Corporate Governance }\end{array}$ & $\begin{array}{l}\text { Dependent Variables: Intellectual } \\
\text { Capital Components }\end{array}$ \\
\hline Disclosure and transparency & Human Capital \\
\hline Protection of Shareholders' rights & Structural Capital \\
\hline Shareholders equality & Relational Capital \\
\hline Shareholders role & \\
\hline Board of Directors Responsibilities & \\
\hline
\end{tabular}

Figure 1: Study model

\section{Chapter II: Theoretical framework and previous studies}

\subsection{Corporate Governance}

The world is currently witnessing many events and developments that are leading largely to increased competition between different companies; a competition that has pushed many managements to follow the wrong financial and administrative policies. Such decisions represent a type of unethical professional behavior that seeks to achieve personal benefits on the expense of shareholders causing the collapse of these companies. Therefore, it is necessary to rely on modern policies and procedures for management and supervision that can be the base to ensure the protection of capital by the activation of transparency, accountability, and justice among the various parties related to the organization (Amarneh \& Yaseen, 2013). These policies and procedures were represented in corporate governance (Samarasiri, 2008), which the OECD identified as "A system of rules and relationships that exist between all parties who have common interests with the company - represented by the company's management, board of directors, owners, and others. Corporate Governance is considered a method that provides the general framework in which to set goals, achieve them, monitor and direct performance, oversee, and determine the exact results and successful methods to exercise power that supports the provision of necessary incentives for the Board of Directors and senior management in order to achieve specific goals related to serving the interests of the company and its shareholders, and to facilitate good control leading to the efficient and effective use of the company's resources" (OECD, 2004).

The principles established by the (OECD) area foundation to curb irregularities and violation that the shareholders might suffer from. These principles include (OECD, 2004): 1. Protection of Shareholders' Equities: Refers to the Protecting the equities of shareholders and facilitating the exercise of their rights.

2. Equitable Treatment of Shareholders: Refers to fair treatment of shareholders, including minority shareholders, foreign shareholders. It also ensures shareholders the opportunity to obtain effective compensation for the violation of their rights.

3. Role of Stakeholders: refers to the recognition of stakeholders' equities as established by the law or as set out in the mutual agreements, and the encouragement of cooperation between companies and stakeholders in creating wealth, job, and financial sustainability of the companies. 
4. Responsibility of the Board of Directors: Refers to the presence of a strategic guide for the company and an effective monitoring of the management by the council and its accountability to the company and shareholders.

5. Disclosure and Transparency: refers to the precise and timely disclosure of financial matters relating to the company. It also refers to the company's financial position, performance, ownership, and management.

6. Ensure the existence of a foundation for an effective institutional framework for governance: refers to the need to build an effective legal and organizational foundation all parties in the market can rely onto construct and establish private contractual relations. The effective framework for corporate governance is characterized with flexibility and ability to undergo modification due to changing business conditions and the accumulation of experiences, provided that the undergoing development is consistent with overall economic performance, market integrity, individual motives in the market, and the level of transparency and efficiency in the market. The construction and development of an effective framework for institutional governance requires compatibility and harmony between legal and regulatory requirements that affect the application of the corporate governance and the rules, procedures, transparency, and the possibility of execution.

\subsection{Intellectual Capital}

The great result of focus on knowledge and its source was drawing attention to the intellectual capital as one of the non-physical assets of an organization, a product of the knowledge-based economy, the source of the intellectual powers, and the key to achieving the organizations objectives and improving its performance in the new knowledge environment. Therefore, intellectual capital is one of the most important properties of an organization.

Intellectual capital is defined as "The ability to transfer knowledge and intangible assets to mechanisms that contribute in the creation of real wealth" (Stewart, 1997, 95). It was also defined as "Everything that is used to generate the wealth of the organization, which translates to a value that contributes to achieving the objectives of the organization, which in turn consists of all the intellectual resources owned, including knowledge, ideas, information, expertise, skills, technology, and necessary and required relations with customers to increase the ability to compete in the work environment and achieve excellence and innovation (Edvins son, 2002, 243).

Intellectual capital is a summary of the interaction of a set of components that contributed to the formation and composition of its final version. The previous definitions have indicated that the human element is the foundation of the final version of the intellectual capital. However, this does not eliminate the fact that there are inputs and other components that contribute to the formation and support the human elements to achieve the final result.

Administrative authors, thinkers, and economists have various opinions on determining the basic components of intellectual capital. This has led to the emergence of multiple models for these components. The most famous model, however, was developed by (Stewart, 1997). He divided the components of intellectual capital to

Human capital;

Structural capital;

Relational capital. 
The combination of the above components generates a real value for the overall intellectual capital of the organization.

\section{Human Capital}

The human capital represents the source of creativity, innovation, improvement, and development in the organization (Donnell et al., 2000). It consists of knowledge, skills, experience and expertise, mental and intellectual capacity based in the human mind of a group of individuals working in the organization. Therefore, it's a property of the organization (Bonits, 1998 0.66). Human capital is important due to its ability to achieve excellence and creativity in the organization by offering new ideas and proposals to solve problems faced by the Organization (Sveiby, 2003, 75). Human capital is one of the renewable elements of the organization. This component grows and increases with the accumulation of knowledge and experience that are applied on the ground. However, it is difficult to measure (Donnell et al., 2000).

\section{Structural Capital}

The structural capital represents the organizational structure of the organization and the main pillar upon which human capital relies (Bontis et al., 1999).It is considered one of the basic properties of an organization (Lovingsson, 2000). It consists of the organizations' policies, visions, information systems and bases, organizational capabilities, and adopted methods and procedures used to reformulate knowledge and implement it in order to achieve the organization's objectives (Ross et. Al., 1997), and provide support while facing the events and variables of the work environment and the market (Bontis, 2000), such as patents, production licenses, trademarks (Brookings, 1997, 364).

\section{Relational Capital}

The relational capital represents an added value to the organization, which is determined by the nature of the relations between the organization and all individuals and entities that share interests and relationships with the organization, like common importers, competitors (Edvinson, 1997, 369), and clients who deal with the organization and provide ideas and proposals that contribute in the development, growth, and continuity processes (Bontis et al., 1999). Relational capital is determined by the organization's ability to retain clients, gain their loyalty and satisfaction, and attract new clients (Kaplan \& Norton, 1996). It is also determined by the size of the organization's market share, the rate of market growth, trademark, and the organization's reputation in the market (Chen et al. 0.2004). This component is the most valuable components of the intellectual capital. It can be easily measured based on the organization's revenues from services and products provided to clients (Donnell, et al., 2000).

\section{2-3 Previous Studies}

The researcher has surveyed previous relevant studies so as to build a conceptual framework on which the current study can rely on to detect the fundamental aspects of its dimensions. The researcher believes it is possible to divide the previous studies to three areas as follows:

First, Studies related to Corporate Governance

(Brown \&Caylor, 2004) study attempted to measure the relationship between corporate governance and performance based on different standards of corporate governance that were used from the institutional shareholder services. The study included the result of 
measuring (51) factor that included (8) categories of governance. It was based on the descriptive and analytical approach, where governance categories and standards of performance based on the management environment were linked. The study found a positive relationship between the level of corporate governance application and the amount of profitability, since the companies that have relatively better level of governance can be more profitable, enjoy a higher value, and pay more money to shareholders.

(Kanellos \& George, 2007) study attempted to determine the nature of the relationship between governance and the performance of Greek companies that were listed in Greece Stock Exchange and applied governance standards during the period 2004 to 2005.This objective was achieved by using a questionnaire that was distributed to executives working in the 314 companies that were part of the study. The companies have been classified into three groups based on how they applied the standards of corporate governance and used (Fama \& French) model to test governance, namely: democratic companies, semi-democratic companies, and dictatorship corporate. The study found that most of the listed companies in the Greece Stock Exchange belong to the second part, semi-democratic companies. The study also found that companies that apply good governance standards have performed better than the ones that applied weak standards.

(Black et al., 2008) has expanded its range to disclose the nature of the relationship between corporate governance and the value of the company. It sought to identify channels that corporate governance depend on in influencing the company's value, based on a survey conducted on public companies listed in the Korean stock market from 1998 to 2004, which represents the sample of the study. A manual method was used to collect data from the annual reports, companies' websites, and online businesses. The study found a positive relationship between the corporate governance index and the market value of the company. It also adopted a set of channels that institutional governance can use to lift the total value of the company through more efficient operations.

(Velnampy, 2013) study addressed the relationship between corporate governance and corporate performance by studying a sample of 28 industrial companies listed in Colombo Stock Market until 2012. The study used the analytical descriptive approach and relied on the annual reports for companies to extract the data that represents the period between 2007 and 2011. The study found that corporate governance is not significantly associated with the revenue of the shareholders rights and the revenue of assets, which are considered as performance measures.

\section{Second, Studies related to intellectual capital}

(Xinyu, 2014) study attempted to examine the relationship between intellectual capital and the performance of Chinese companies. It then compared this effect between state companies and Western companies in the same sector, using and a sample of (144) Chinese company and (114) Western company between 2010 and 2012. The study measured intellectual capital and the coefficient of intellectual capital's added value (VAIC), and the ratios (return on assets return on rights of ownership, profitability of the common stock, current ratio, quick ratio, rapid assets turnover rate, property rights multiplier, assets to liabilities ratio, inventory turnover, and receivable accounts turnover rate) to measure performance. The study revealed the existence of a positive correlation between the financial capital, human capital, corporate performance, and the lack of impact on the structural capital among Chinese and Western companies. The study also 
discovered the presence of a positive correlation between the human capital and the performance of Western companies in a way that surpasses Chinese companies.

(Dadashinasab et al., 2015) attempted to test intellectual capital performance and its association with the financial performance of banks and financial institutions in Iran. The study relied on a sample composed of all banks and financial institutions listed in Tehran Stock Market during the period (2007-2012). The study used three indicators for efficiency: Working Capital Efficiency (CEE), Human Capital Efficiency (HCE), and Structural Capital Efficiency (SCE). The study used the rate of return on equity (ROE) as a measure of financial performance of banks and financial institutions. The study found a positive and statistically significant relationship between(VAIC), (HCE), (SCE), and (ROE, and a negative relationship that is not statistically significant between (CEE) and financial performance.

(Aslam\& Amin, 2015) sought to identify the impact of intellectual capital on financial vulnerability (FV) for the pharmaceutical industries sector in Pakistan. The study believed that intellectual capital is usually calculated as a strategic asset for the company and is used to generate value to maintain a competitive advantage. You can create intangible value through perceptions which are not usually included in the annual reports, but are useful to cope with financial shocks. Quantitative data has been collected from the annual reports of the listed pharmaceutical industry sector in Pakistan to test a pilot study. The study results showed a significant effect on the efficiency of intellectual capital on the financial vulnerability of the Pakistani pharmaceutical companies.

\section{Third, Studies related to corporate governance and intellectual capital}

(Makki \& Lodhi, 2014) aimed to develop a structural model linking corporate governance, efficiency of intellectual capital, and financial performance. Corporate governance has been pictured and measured by CEO duplication and the proportion of non-executive directors, executives, and a number of shareholders. Intellectual capital adequacy was calculated by the value added to the coefficient of intellectual capital (VAICTM), while financial performance was represented through the return on investment, return on equity, and net profit after tax. The study revealed the existence of a critical structural relationship between corporate governance and efficiency of the intellectual capital and financial performance. It concluded that corporate governance does not improve the financial performance directly, but it can boost it significantly by exploiting intellectual capital resources.

We can conclude that there are a limited number of previous studies linking the subject of corporate governance to intellectual capital of industrial companies. This fact gives this study an advantage and makes it stand out from other studies.

\section{Chapter 3: Study methodology and procedures}

This is a descriptive and analytical study that aims to identify the level of commitment to corporate governance in the Jordanian Public Shareholding Industrial Companies, and the effect of such commitment on the efficiency of intellectual capital. This study is based on inductive approach and analytical, descriptive approach, which are also the most common methods used in management, accounting, and auditing researches. The first method was used in analyzing the previous studies, articles, research, periodicals, and both in the corporate governance and intellectual capital in a way that made it possible to build a theoretical framework for the study, establish a study model, determine the extent of 
adherence to the principles of corporate governance, and the ability to predict the efficiency of intellectual capital.

The second method is the descriptive and analytical approach, which is based on the use of various statistical methods and standard for the analysis of financial data gathered from the reports of industrial companies, so as to measure the independent and dependant variables of the study.

\section{3-1 The study's population and sample}

The study population consisted of all Jordanian industrial public shareholding companies, which are (71) companies. A sample 63 companies was selecting (88.7\% of the size of the population of industrial companies). Only companies that met the following conditions were selected:

1. The company has never underwent liquidation and does not struggle financially;

2. The company's shares are traded during the period of the study (2012-2015), and did not stop trading during the period.

3. The company publishes its financial statements without interruption during the period (2012-2015).

\section{3-2 Measuring the study's variables}

\subsubsection{Dependent variable: intellectual capital efficiency}

The dependent variable in the study is the value added to intellectual capital and its components.

Researcher (Pulic, 1998) has developed an index to indirectly measure intellectual capital through its contribution to the of an added value for the company, known as a "Value Added Intellectual Coefficient (VAIC)". It's the value generated of the efficiency of the capital (intellectual, structural, and physical), in addition to the adoption of some studies on creative and relational capital (client-related). A large number of researchers used this method in studies such as (Puntillo, 2009) study, (Nazari, 2010), (Nogueira et al., 2010), (Whiting, 2011), (Clarke et al., 2010), and (Zhang, 2014), which can be explained through the following steps:

$\mathbf{1}^{\text {st }}$ step: Calculate the company's ability to create an added value, in other words: to what extent are company's resources able to create an added value. The gross value added of the company (VA) is calculated as follows:

Where:

$$
\mathrm{VA}=\mathrm{OUT}-\mathrm{INP}
$$

$\mathrm{VA}=$ value added to the company.

OUT $=$ output of the company; which is composed of operations of the company's income.

INP = input of the company; which is composed of operational costs except wages and salaries that are not considered the costs of expenses for this purpose.

$\mathbf{2}^{\text {nd }}$ step: Estimating the relationship between the gross value added (VA) and human capital (HC) by measuring human capital efficiency (HCE).In other words, how much value added is created as a result of investment a monetary unit in human resources, which is measured as follows:

$$
\mathrm{HCE}=\mathrm{VA} / \mathrm{HC}
$$

Where:

$\mathrm{HCE}=$ human capital efficiency.

$\mathrm{VA}=$ value added to the company. 
$\mathrm{HC}=$ Value of human capital (Total salaries and wages of the company).

$3^{\text {rd }}$ Step: Find a relationship between the gross value added (VA) and the structural capital (SC) by measuring the structural capital efficiency (SCE). In other words, how much value is created as a result of investing in the structural capital. According to (1998, pulic) structural capital is calculated as follows:

$\mathrm{SC}=\mathrm{VA}-\mathrm{HC}$

Where:

$\mathrm{SC}=$ Structural capital value.

$\mathrm{VA}=$ Value added for the company.

$\mathrm{HC}=$ Human capital value.

This equation indicates that structural capital is not a separate index and that it depends on human capital contribution to the creation of value-added. The higher the human capital's contribution to the creation of value-added, the less the structural capital's contribution to the creation of value-added, and thus the structural capital efficiency (SCE) is as follows:

$$
\begin{aligned}
& \text { SCE = SC / VA } \\
& \text { Where: } \\
& \text { SCE = Structural capital efficiency. } \\
& \text { SC = Structural capital value. } \\
& \text { VA = value added to the company. }
\end{aligned}
$$

$4^{\text {th }}$ Step: calculate intellectual capital efficiency (ICE), which describes the intellectual capital contribution (IC) in the creation of value-added. Intellectual capital efficiency (ICE) is obtained by adding human capital efficiency (HCE) to structural capital efficiency (SCE) as follows:

$$
\mathrm{ICE}=\mathrm{HCE}+\mathrm{SCE}
$$

$5^{\text {th }}$ Step: Estimate the relationship between the gross value added (VA) and relational capital (RC) by measuring the efficiency of capital relational (RCE). In other words, how much value is created as a result of spending a single monetary unit on advertising, research, and development expenses, which is measured as follows:

Where:

$$
\mathrm{RCE}=\mathrm{RC} / \mathrm{VA}
$$

$\mathrm{RCE}=$ relational capital efficiency.

$\mathrm{VA}=$ value added to the company. expenses).

$\mathrm{RC}=$ relational capital value(Total advertising, research, and development

\subsubsection{Independent variables: the principles of corporate governance}

An index was established to determine the level of commitment to the principles of corporate governance, depending on the level of disclosure in the annual reports, as follows:

The level of commitment $=$ the number of provisions in a principle $/$ All items to be adhered to $* 100 \%$

The number (1) is set in the case of commitment, and the number (0) in the case of noncompliance.

\section{3-3 Descriptive analysis of the study sample's variables}

First, Describe the level of commitment to principles of corporate governance

Table 1 shows the statistical description of the level of commitment to the principles of corporate governance during the period (2012-2015) 
The Impact of Corporate Governance Principles on Intellectual ....

\begin{tabular}{|l|c|c|c|c|}
\hline \multicolumn{1}{|c|}{$\%$} & Mean & St.dev & Max & Min \\
\hline Disclosure and Transparency & 67.50 & 11.75 & 78.55 & 45.33 \\
\hline Protection of shareholders' rights & 71.75 & 10.85 & 83.37 & 56.77 \\
\hline Shareholders equality & 42.12 & 25.16 & 66.89 & 19.56 \\
\hline Shareholders role & 39.82 & 21.40 & 60.73 & 17.46 \\
\hline Board of Directors responsibility & 68.05 & 13.10 & 86.88 & 50.09 \\
\hline Corporate Governance & $\mathbf{5 7 . 8 5}$ & $\mathbf{1 4 . 2 1}$ & $\mathbf{6 9 . 7 6}$ & $\mathbf{4 1 . 2 2}$ \\
\hline
\end{tabular}

Table 1 refers to the difference in the level of adherence to the principles of governance in Jordanian industrial companies. (Protection of shareholders' rights) scored the highest proportion of commitment, which amounted to (71.75), while the lower level of commitment was for (the role of stakeholders), which amounted to (39.82\%). In addition, the level of commitment to the principles of governance, the level of disclosure, was $(57.85 \%)$. These results indicate the weak commitment of industrial companies to the principles of governance. This weakness of commitment and disclosure may be due to a lack of attention of supervisory authorities who should be forcing industrial companies to adhere to the principles of governance.

Second: Describe the efficiency of intellectual capital components

Table 2 shows the statistical description of the efficiency of intellectual capital during the period (2012-2015)

\begin{tabular}{|l|c|c|c|c|}
\hline \multicolumn{1}{|c|}{$\%$} & Mean & St.dev & Max & Min \\
\hline Human Capital Efficiency (HCE) & 1.66 & 6.36 & 26.91 & -58.11. \\
\hline Structural Capital Efficiency (SCE) & 0.89 & 4.49 & 53.56 & -13.12 \\
\hline Relational Capital Efficiency (RCE) & 0.20 & 0.71 & 11.67 & -1.41 \\
\hline
\end{tabular}

Table 2 indicates the presence of a considerable variation in the efficiency of intellectual capital's components between industrial companies. This variation has stemmed from the values of standard deviation, and maximum and minimum values. This indicates to the variation between companies in terms of interest in investing in intellectual capital; an interest that has reflected on increasing the value in the company. The arithmetic mean has indicated, in terms of the human capital efficiency, that every dinar spent on the development of human resources will accrue to the company at a rate of (1.66) dinars, and this value reflects the human capital efficiency in industrial enterprises. However, the value of the standard deviation (6.36) indicates the presence of dispersion in human capital efficiency values. The greatest recorded value (26.91) and the lowest value (58.11) have proven the existence of this dispersion. The case did not differ much regarding structural and relational capital efficiency, but their average value of efficiency did not amount to (1).

\section{3-4 Testing the study's hypotheses}

The study sample includes Jordanian public shareholding industrial companies during the period (2012-2015).Data has been collected for these uses for the cited period, thus the study's data are cross-sectional time series data. Multiple regression analysis is the most appropriate model to measure the relationship between variables. This part of the study tests the hypotheses after confirming the suitability of the data for the study model and the description of the study's variables. 
Table 3 shows the results of testing the hypotheses where the effect of adherence to the principles of corporate governance on the intellectual capital efficiency in the Jordanian industrial public shareholding companies was tested. The components of intellectual capital included (HCE, SCE, and RCE).The results of the tests were presented as follows:

Table 3 Results of testing the hypotheses of the study

\begin{tabular}{|c|c|c|c|c|}
\hline \multirow[t]{3}{*}{$\begin{array}{l}\text { Independent } \\
\text { variables }\end{array}$} & $\begin{array}{c}\text { First hypothesis } \\
\text { H01 }\end{array}$ & $\begin{array}{c}\text { Second } \\
\text { hypothesis } \\
\text { H02 }\end{array}$ & $\begin{array}{c}\text { Third } \\
\text { hypothesis } \\
\text { H03 }\end{array}$ & \\
\hline & $\begin{array}{c}\text { Dependant } \\
\text { variable }\end{array}$ & $\begin{array}{c}\text { Dependant } \\
\text { variable }\end{array}$ & $\begin{array}{c}\text { Dependant } \\
\text { variable }\end{array}$ & \\
\hline & HCE & SCE & RCE & VIF \\
\hline \multirow{2}{*}{$\begin{array}{l}\text { Disclosure } \\
\text { and } \\
\text { Transparency }\end{array}$} & 0.019 & 0.020 & 0.018 & 2.087 \\
\hline & $(16.396)^{* * *}$ & (1.713) & $(14.708)^{* *}$ & \\
\hline \multirow{2}{*}{$\begin{array}{l}\text { Protection of } \\
\text { shareholders' } \\
\text { equity }\end{array}$} & 0.030 & 0.039 & 0.045 & 2.824 \\
\hline & $(7.588) * *$ & $(7.022) * *$ & $(8.328)^{* *}$ & \\
\hline \multirow{2}{*}{$\begin{array}{l}\text { Shareholders } \\
\text { equality }\end{array}$} & 0.001 & 0.004 & 0.001 & 2.713 \\
\hline & $(0.677)$ & $(0.467)$ & $(1.103)$ & \\
\hline \multirow{2}{*}{$\begin{array}{l}\text { Shareholders } \\
\text { role }\end{array}$} & 0.041 & 0.089 & 0.030 & 1.795 \\
\hline & $(0.510)$ & $(1.328)$ & $(0.638)$ & \\
\hline \multirow{2}{*}{$\begin{array}{l}\text { Board of } \\
\text { Directors } \\
\text { responsibility }\end{array}$} & 0.060 & 0.079 & 0.058 & 1.698 \\
\hline & $(3.208) * *$ & $(2.067)^{*}$ & (1.838) & \\
\hline $\begin{array}{l}\text { Determination } \\
\text { coefficient } \mathrm{R}^{2}\end{array}$ & 0.344 & 0.134 & 0.225 & \\
\hline \multirow{2}{*}{$\begin{array}{c}\text { Calculated } \\
\text { value of } F \\
D-W\end{array}$} & $(45.110)^{* * *}$ & $(20.289)^{* *}$ & $(30.826) * *$ & \\
\hline & 1.911 & 1.823 & 1.871 & \\
\hline
\end{tabular}

*Significant at the level of significant 0.05

** Significant at the level of significant 0.01

Note: The value in the first row refers to the value of the regression coefficient, while the second row, which is between the brackets, refers to the value of t. Note that the total views amounted to 252 views

Depending on Table 3 above, we can conclude the following:

1. Testing the results of the first hypothesis: The results of Table (3) show that the effect of adherence to the principles of corporate governance combined on human capital efficiency is a significant effect, where the value of $(F=45.110)$ and the level of significance is less than 0.01 . The value of the determination coefficient $\left(R^{2}=0.344\right)$ indicated that the $34.4 \%$ of the variation in the human capital efficiency can be explained by the combined variables. The results also showed that the value of the regression coefficients, the impact (disclosure and transparency), has a significant effect, where the value of the regression coefficient was (0.019), and the level of significance was less than 0.01.The impact of (protection of shareholders' equities) was significant, as the value of 
the regression coefficient was (0.030), and the level of significance was less than 0.01.The effect of (responsibility of the board of Directors) was significant, as the value of the regression coefficient was (0.060), and the level of significance was less than 0.01. Meanwhile, the remaining of the principles of corporate governance had no significant effect on human capital efficiency. Accordingly, we reject the first hypothesis and accept the alternative, which states: "There is a statistically significant impact at the level of significance $(\alpha \leq 0.05)$ for the principles of corporate governance on the human capital in Jordanian Public Shareholding industrial companies.

2. Testing the results of the second hypothesis: The results of Table (3) show that the effect of adherence to the principles of corporate governance combined on structural capital efficiency is a significant effect, where the value of $(\mathrm{F}=20.289)$ and the level of significance was less than 0.01 . The value of the determination coefficient $(\mathrm{R} 2=0.134)$ indicated that the $13.4 \%$ of the variation in the structural capital efficiency can be explained by the combined variables. The results also showed that the value of the regression coefficients, the impact (protection of shareholders' equities) has a significant effect, as the value of the regression coefficient was (0.039), and the level of significance was less than 0.01. The impact of (responsibility of the board of Directors) was significant, as the value of the regression coefficient was (0.079), and the level of significance was less than 0.05 . Meanwhile, the remaining of the principles of corporate governance had no significant effect on structural capital efficiency. Accordingly, we reject the second hypothesis and accept the alternative, which states: "There is a statistically significant impact at the level of significance $(\alpha \leq 0.05)$ for the principles of corporate governance on the structural capital in Jordanian Public Shareholding industrial companies.

3. Testing the results of the third hypothesis: The results of Table (3) show that the effect of adherence to the principles of corporate governance combined on relational capital efficiency is a significant effect, where the value of $(F=30.826)$ and the level of significance was less than 0.01 . The value of the determination coefficient $(\mathrm{R} 2=0.225)$ indicated that the $22.5 \%$ of the variation in the relational capital efficiency can be explained by the combined variables. The results also showed that the value of the regression coefficients, the impact (disclosure and transparency) has a significant effect, as the value of the regression coefficient was (0.018), and the level of significance was less than 0.01 . The impact of (protection of shareholders' equities) was significant, as the value of the regression coefficient was (0.045), and the level of significance was less than 0.05 . Meanwhile, the remaining of the principles of corporate governance had no significant effect on relational capital efficiency. Accordingly, we reject the second hypothesis and accept the alternative, which states: "There is a statistically significant impact at the level of significance $(\alpha \leq 0.05)$ for the principles of corporate governance on the relational capital in Jordanian Public Shareholding industrial companies.

\section{Chapter Four: Results and Recommendations}

The results of the descriptive analysis of the level of commitment to the principles of corporate governance and its disclosure indicated a discrepancy in this commitment, which was low a bit. This low figure was attributed to the weakness of the methods and rules applied within the industrial companies, which include reliance on administrative structures that do not properly explain how decisions are made within the company and the distribution of positions, powers, and duties between individuals on the application of corporate governance. It is also attributed to the absence - and unclearness - of laws and 
regulations concerned with organizing work in the markets, in addition to the absence of the role of the regulatory and supervisory authorities that force industrial companies to adhere to the principles of corporate governance, not to mention the lack of specialists concerned with the application of corporate governance and lack of sufficient and specialized knowledge in this field.

Results of descriptive analysis of the efficiency of intellectual capital components have also shown a discrepancy between industrial companies in terms of interest in investing in intellectual capital. This is due to the fact that the management of industrial companies perceive the importance of intellectual capital and its impact on performance differently, and the different nature of relations set up by the industrial companies with clients, suppliers, and partners, in addition to the variety of accumulated information and expertise in industrial companies, and intellectual property, capabilities, innovative and creative abilities, and the nature of technology used in industrial companies based on the difference in the age, focus, and size of assets of industrial companies. Another factor is the difference in the strategies industrial companies use to measure and manage intellectual capital and determine the basic criteria in highlighting the intellectual competencies, not to mention high investment expenditures in intellectual capital compared to its revenue.

The results of testing the hypotheses has shown a statistically significant effect at the level of significance $(\alpha \leq 0.05)$ for adhering to the principles of corporate governance on intellectual capital efficiency (human capital, structural capital, and relational capital) in the Jordanian Public Shareholding industrial companies. The reason behind this impact is that corporate governance and the principles it summoned promote the creation of a healthy working environment, drive it towards achieving better performance, provide good management, document workflow and procedures within the company, teach corporate how to organize its knowledge performance. The application of corporate governance can reflect the true value of companies by offering transparent and clear data, pushing companies towards increasing efficiency, profitability, competitiveness, and ability to achieve goals through planning and funding research and development processes. It also encourage companies to focus on raising the capacity of workers, rely on training programs, diagnose the company's resources, and promote innovation for excellence in products and services.

Based on the findings of the study, the author recommends that industrial companies rely on administrative structures that properly explain how decisions are made within the company and how positions, powers, and duties are distributed between individuals concerned by the application of corporate governance. The role of the regulatory and supervisory authorities should be activated to drive industrial companies to adhere to the principles of corporate governance, and provide a cadre specialized in the application of corporate governance. This cadre should be given all the necessary powers to carry out their work and resources.

The study also suggests that the managements of industrial companies should recognize the importance of intellectual capital and its impact on its performance. They should also make the most of information, expertise, intellectual property, and innovative and creative capabilities accumulated in industrial companies. They should work on the modernization and development of systems and programs that commensurate with its resources and potential, and rely on more efficient strategies that is completely able to measure and 
manage intellectual capital, and allocate financial resources for investment in intellectual capital.

The study also recommends that managements of industrial companies rely on an effective framework for corporate governance; a framework that can highlight the role and importance of intellectual capital, its fields, requirements of modernization and development, and how to invest it. They should also disclose clearly and transparently the progress of work and procedures within the company and how companies regulate their knowledge performance. Finally, the study recommends the conduction of more research and studies on other sectors and the adoption of new variables.

\section{References:}

- Amarneh, Asmaa\&yaseen, Hadeel (2013). Corporate Governance and Leverage: Evidence from the Jordanian Stock Market. Research Journal of Finance and Accounting, Vol. 4, No. 19.

- Aslam, Shoaib\& Amin, Shahid (2015). Impact of Intellectual Capital on Financial Vulnerability of Pharmaceuticals Sector in Pakistan. Pakistan Journal of Commerce and Social Sciences, Vol. 9, No. 1, P. 171-184.

- Black, B. S.; Kim, W.; Jang, H. \& Park, K. S. (2008). How Corporate Governance Affects Firm Value: Evidence on Channels from Korea. From http:// ssrn. com.

- $\quad$ Bonits, N. (1998). Intellectual Capital: An Exploratory Study that Develops Measures and Models. Management Decision, Vol. 36, No. 2.

- Bontis, Nick (2000). Intellectual Capital and Business Performance in Malaysian Industries. Journal of Intellectual Capital, Vol. 1, No. (1), p. 85-100.

- Bontis, Nick; Dragonetti, N. C.; Jacobsen, K. \&Roos, G. (1999). The Knowledge Toolbox: A Review of the Tools Available to Measure and Manage Intangible Resources. European Management Journal, Vol. 17, No. (4), p. 391-402.

- $\quad$ Brookings, A. (1997). The Management of Intellectual Capital. Long Range Planning, Vol. 30, No. 3.

- $\quad$ Brown, Lawrence \&Caylor, Marcus (2004). Corporate Governance and Firm Performance.

- $\quad$ Chen, J., Zhaohui, Z. \& Hong, Y. X. (2004). Measuring Intellectual Capital a New Model and Empirical Study of Intellectual Capital. Journal of Intellectual Capital, Vol. 5, No. 1.

- $\quad$ Dadashinasab, Majid; Mousavi, Seyyed; Ghorbani, Behzad\&Khatiri, Mohammed (2015). Intellectual Capital Performance of Financial Instituations in Iran.Walia Journal, Vol. 31, No. S3, P 56 - 60.

- Donnell, David, Regan, Philip \& Coates, Brian (2000). Intellectual Capital: A Habermasian Introduction. Journal of Intellectual Capital, Vo. 1, No. 2, UK.

- $\quad$ Edvinsson, L. (1997). Developing Intellectual Capital at Skandia. Long Range Planning, Vol. 30, No. 3.

- $\quad$ Edvinsson, L. (2002). Corporate longitude. Prentice Hall, London.

- Kanellos, T. \& George, T. (2007). Corporate Governance and Firm Performance: Results from Greek Firm. http:// .ssrn.com//.

- Kaplan, R. \& Norton, D. (1996). The Balanced Scorecard: Measures That Drive Performance. HBR, Vol. 70, No. (1), p. 1-79. 
- $\quad$ Lovingsson, Fredrik (2000). Navigating with New Managerial Tools. Journal of Intellectuall Capital, Vol. 1, No. 2, p. 147 - 154.

- Makki, Muhammad Abdul Majid\&Lodhi, Suleman Aziz (2014). Impact of Corporate Governance on Intellectual Capital Efficiency and Financial Performance.Pakistan Journal of Commerce and Social Sciences, Vol. 8, No. 2, P. 305-330.

- $\quad$ OECD, OECD Principles of Corporate Governance, (2004).

- $\quad$ Ross, J.; Ross, G.; Dragonetti, N. \&Edvinsson, L. (1997). Intellectual Capital: Navigating in the New Business Landscape. Macmillan Business, London.

- $\quad$ Samarasiri, P. (2008). The Need for a New Version of Corporate Governance for Promotion of Risk Managements in Banks. Central Bank of Sirilanka.

- $\quad$ Stewart, T. A. (1997). Intellectual Capital: the Wealth of Organization. Doubled/Currency, New York.

- Sveiby, K. E. (2003). The Intangible Assets Monitor. Journal of Humman Resources Costing and Accounting, Vol. 2, No. 1.

- Velnampy, T. (2013). Corporate Governance and Firm Performance: A Study of Sri Lankan Manufacturing Companies. Journal of Economics and Sustainable Development, Vol. 4, No. (3), P. 228- 236.

- Xinyu, Zhang (2014). The Impacts of Intellectual Capital of Chinas Public Pharmaceutical Company on Companys Performance. Journal of Chemical and Pharmaceutical Reasearch, p. 999 - 1004. 